University of Nebraska - Lincoln

DigitalCommons@University of Nebraska - Lincoln

USDA National Wildlife Research Center - Staff Publications
U.S. Department of Agriculture: Animal and Plant Health Inspection Service

2016

\title{
Susceptibility of rock doves to low-pathogenic avian influenza A viruses
}

Susan A. Shriner

USDA/APHIS/WS National Wildlife Research Center, susan.a.shriner@aphis.usda.gov

J. Jeffrey Root

USDA/APHIS/WS National Wildlife Research Center, jeff.root@aphis.usda.gov

Nicole L. Mooers

National Wildlife Research Center, United States Department of Agriculture/Animal and Plant Health Inspection Service/ Wildlife Services, Fort Collins, CO

Jeremy W. Ellis

National Wildlife Research Center, United States Department of Agriculture/Animal and Plant Health Inspection Service/ Wildlife Services, Fort Collins, CO

Scott R. Stopak

Wildlife Services, United States Department of Agriculture/ Animal and Plant Health Inspection Service, Boise, ID

See next page for additional authors

Follow this and additional works at: https://digitalcommons.unl.edu/icwdm_usdanwrc

Part of the Life Sciences Commons

Shriner, Susan A.; Root, J. Jeffrey; Mooers, Nicole L.; Ellis, Jeremy W.; Stopak, Scott R.; Sullivan, Heather J.; VanDalen, Kaci K.; and Franklin, Alan B., "Susceptibility of rock doves to low-pathogenic avian influenza A viruses" (2016). USDA National Wildlife Research Center - Staff Publications. 1793.

https://digitalcommons.unl.edu/icwdm_usdanwrc/1793

This Article is brought to you for free and open access by the U.S. Department of Agriculture: Animal and Plant Health Inspection Service at DigitalCommons@University of Nebraska - Lincoln. It has been accepted for inclusion in USDA National Wildlife Research Center - Staff Publications by an authorized administrator of DigitalCommons@University of Nebraska - Lincoln. 


\section{Authors}

Susan A. Shriner, J. Jeffrey Root, Nicole L. Mooers, Jeremy W. Ellis, Scott R. Stopak, Heather J. Sullivan, Kaci K. VanDalen, and Alan B. Franklin 


\title{
Susceptibility of rock doves to low-pathogenic avian influenza A viruses
}

\author{
Susan A. Shriner ${ }^{1}\left(\mathbb{D} \cdot{\text { J. Jeffrey } \operatorname{Root}^{1} \cdot \text { Nicole L. Mooers }}^{1} \cdot\right.$ Jeremy W. Ellis $^{1} \cdot$ \\ Scott R. Stopak ${ }^{2} \cdot$ Heather J. Sullivan $^{1} \cdot$ Kaci K. VanDalen ${ }^{1} \cdot$ Alan B. Franklin ${ }^{1}$
}

Received: 2 September 2015 / Accepted: 11 November 2015/Published online: 21 December 2015

(C) Springer-Verlag Wien (outside the USA) 2015

\begin{abstract}
Following a 2008 outbreak of North American low-pathogenic H5N8 influenza A virus at an upland gamebird farm, we sero-sampled rock doves (pigeons, Columba livia) at the outbreak site and conducted experimental inoculations of wild-caught pigeons using the H5N8 virus and another low-pathogenic virus (H4N6). While $13 \%$ of pigeons at the outbreak site were seropositive, none were positive for exposure to H5, and one was positive for N8. Challenged pigeons exhibited low susceptibility and limited viral RNA excretion for both viruses tested, but at least one individual had RNA loads indicative of the potential for viral transmission to other birds.
\end{abstract}

Rock doves (Columba livia; hereafter, pigeons) are frequently associated with poultry operations as synanthropes, are one of the most common birds found in large urban areas, are often associated with wet markets, and are a common poultry species in Asia. Consequently, pigeons are likely to be regularly exposed to avian influenza A viruses (IAVs). Nonetheless, field surveys of pigeons often show relatively low seroprevalence, and experimental studies have generally demonstrated high resistance and limited susceptibility to multiple strains of avian IAVs (reviewed in references [1] and [9]). While the handful of

Susan A. Shriner

Susan.A.Shriner@aphis.usda.gov

1 National Wildlife Research Center, United States Department of Agriculture/Animal and Plant Health Inspection Service/ Wildlife Services, Fort Collins, CO 80521, USA

2 Wildlife Services, United States Department of Agriculture/ Animal and Plant Health Inspection Service, Boise, ID 83709, USA studies that have investigated low-pathogenic (LP) IAVs in pigeons have shown that these birds have limited susceptibility, most of those studies have only tested a relatively small number of individuals. The presence of strong individual heterogeneity in IAV shedding rates across bird species $[7,12]$ indicates that relatively large sample sizes are necessary to determine if a small minority of individuals might shed virus at higher rates than average. Because pigeons often congregate in large numbers, even a small proportion of higher-than-average shedders could potentially spread virus within and between poultry operations. Outbreaks of low-pathogenic avian influenza are associated with production losses for poultry operations, and outbreaks of low-pathogenic influenza A H5 or H7 subtypes are reportable diseases that often result in depopulation and severe economic consequences [16]. Pigeons have been shown to preferentially select farms for forage sites and to move between farms [4]; therefore, these birds should be evaluated to determine if they should be considered in biosecurity plans.

Experimental inoculation studies $[1,5,6,9,11]$ have generally shown both limited viral shedding and limited seroconversion in pigeons, especially for LP IAVs. In an experimental inoculation study using both LP and highly pathogenic (HP) IAVs in pigeons, only one of eight oculonasally inoculated birds from a LP group showed evidence of shedding and seroconversion [11]. In another experimental inoculation study, twelve pigeons were simultaneously inoculated orally, intranasally, and orbitally with three H9 strains of IAV. Only three birds shed virus on day one post-inoculation for two of the three strains, and none of four contacts became infected [6]. In another study of LP IAVs in pigeons, 20 birds were inoculated via the oculonasal route with a low-pathogenic $\mathrm{H} 5$ virus, and 16 with an $\mathrm{H6}$ virus [5]. None of the inoculated or contact 
birds showed evidence of infection. Similarly, at least six experimental infection studies using HP IAVs and pigeons have also shown limited susceptibility to the viruses $[8,10$, $13,19,23,24]$. A notable exception to this pattern is a single study that found significant viral shedding of a HP IAV [14]. In that study, 28 pigeons were inoculated intranasally with an HP IAV at various doses (4 birds per dose). Each of the birds in the $10^{6}$ TCID $_{50}$ (median tissue culture infectious dose) group shed virus in high quantities in both oral and cloacal swabs. Moreover, all contact chickens became infected when co-housed with inoculated pigeons. These results underscore the need to study a variety of IAV strains since different strain-host combinations can have variable responses.

In August 2008, an H5N8 LP IAV was isolated from an upland game bird facility in southwest Idaho [17]. The facility raised breeding birds as well as birds released for hunting. The flock included more than 30,000 pheasants, chukars, quail, and mallards. Epidemiologic investigation revealed that in addition to the $\mathrm{H} 5 \mathrm{~N} 8$ virus, a portion of the flock was also infected with LP H4N7 and H11N7 IAVs. Approximately a month after the H5N8 virus was confirmed, pigeons were lethally removed from the site as part of a depopulation effort. We collected serum samples from 31 pigeons and tested them for antibodies to IAV via enzyme-linked immunosorbent assay (ELISA; IDEXX AI MultiS-Screen Ab Test). No age or sex data were available for the samples, but collections occurred in October, so all individuals were likely reproductively mature. Positive samples were subtyped by the National Veterinary Services Laboratory (Ames, IA) using hemagglutinin-inhibition (HI) and neuraminidase-inhibition (NI) assays. Five of 31 pigeons collected from the site were positive for antibodies to IAV via ELISA. Subtyping of the positive samples by HI tests showed that none of the samples were positive for exposure to subtype $\mathrm{H} 5$, but all five exhibited titers of 1:8 or greater, indicative of exposure to influenza A virus subtype H1. Two of those samples also showed titers of 1:8 or greater for exposure to subtype H4. Only four of the five positive samples had adequate sera for NI testing, and one of the four samples that was positive for exposure to both $\mathrm{H} 1$ and $\mathrm{H} 4$ was also identified as positive for exposure to $\mathrm{N} 8$. The finding of samples reactive to an $\mathrm{H} 1$ virus indicates that pigeons were exposed to viruses not associated with the outbreak, likely from a previous time point or potentially from another geographic location. The fact that birds showed exposure to $\mathrm{H} 4$ and $\mathrm{N} 8$ suggests that the pigeons at the outbreak site might have shared IAV infections with the gamebirds that showed exposure to H4N7 or H5N8. However, these results might also represent exposures to wild birds since H4N6 and H3N8 are two of the most common subtypes found in wild birds in North America [15].
Motivated by the outbreak, we experimentally inoculated pigeons to determine if individual heterogeneity could lead to high levels of shedding in at least some individuals. We captured 53 wild pigeons in northern Colorado, primarily from grain silos, outbuildings, and bridges using a combination of hand capture, mistnets, and baited traps. Birds were brought to the National Wildlife Research Center, where they were treated with a light pyrethrin dust (Drione ${ }^{\circledR}$, Bayer AG) and quarantined for at least 14 days, during which all birds were confirmed negative for antibodies to IAV via AGID test and ELISA. We conducted experimental inoculations using two strains of avian LP IAV: A/Pheasant/ID/2590-63/08 (H5N8), isolated from the Idaho outbreak site, and A/mallard/CO/P66F1-5/ 08 (H4N6), isolated from a wild bird during U.S. wild bird surveillance activities [15]. Both viruses were passaged once in allantoic cavities of 9- to 11-day-old specificpathogen-free embryonated chicken eggs at $37{ }^{\circ} \mathrm{C}$. Allantoic fluid was harvested, pooled, and stored at $-80{ }^{\circ} \mathrm{C}$. Viral titers were determined as $50 \%$ egg infectious dose $\left(\mathrm{EID}_{50}\right)$ [21].

Twenty-four birds were inoculated with $10^{6} \mathrm{EID}_{50}$ of the H5N8 virus; 21 of the birds were adults and three were juveniles. Twenty-three birds were inoculated with $10^{6}$ EID $_{50}$ of the H4N6 virus; 21 were adults and two were juveniles. Sexes were not identified. Virus was inoculated orally along the choanal cleft in order to expose both oral and nasal tissues to the viruses. We had two remaining birds available, so they were tested as contact controls. Each was housed with one of the H4N6-inoculated birds. In addition to the contact controls, four birds were used as negative controls and were mock inoculated with diluted amnio-allantoic fluid. Except for the two H4N6 cages with contact controls, all test birds were housed individually. Birds inoculated with the H5N8 virus were housed in micro-isolator cages in a BSL-3 facility, while birds inoculated with the H4N6 virus were housed in stainless steel cages in a BSL-2 animal room. Control birds were cohoused in a large outdoor pen. Oral, cloacal, and fecal swabs were collected daily for 7 days post-inoculation (dpi), and swabs were placed in $1 \mathrm{~mL}$ of BA-1 viral transport medium [14] and stored at $-80{ }^{\circ} \mathrm{C}$ prior to laboratory testing. Serum samples were collected at 16 and 18 dpi for the H5N8 birds and at 7, 15, 21, and 28 dpi for the H4N6 birds. All oral, cloacal, and fecal swabs were tested for IAV RNA via quantitative reverse transcription polymerase chain reaction (RT-qPCR) using an ABI 7900 RealTime PCR System (Life Technologies). Viral RNA was extracted using a MagMAX-96 AI/ND Viral RNA Isolation Kit (Ambion). Primers and probes were specific for the influenza A virus matrix gene [20]. Calibrated controls with known viral titers $\left(10^{2}-10^{5} \mathrm{EID}_{50} / \mathrm{mL}\right)$ were used to construct four-point standard curves, which were used to 
extrapolate sample viral RNA quantities, which are presented as $\mathrm{EID}_{50} / \mathrm{mL}$ equivalents [22].

Seven of the 23 H4N6 birds and two of the 24 H5N8 pigeons shed virus on at least three days post-inoculation. The majority of individuals shed relatively little or no viral RNA post-inoculation. All birds appeared healthy throughout the trials. When detected, viral RNA was predominantly found in oral swabs for both virus strains (Table 1), with positive samples identified for $14 / 24,6 / 24$, $2 / 24$, and $1 / 24$ birds on days $1-4$, respectively, for the H5N8 virus and $17 / 23,8 / 23,7 / 23,3 / 23$, and $3 / 23$ for days $1-5$, respectively, for the H4N6 virus. Only a single bird (ID 49, Table 1) inoculated with the H4N6 virus appeared to excrete viral RNA in quantities likely to be associated with potential viral transmission. No age differences were noted, as results for the five juveniles (IDs 26, 35, and 37 for H5N8 and 59 and 61 for H4N6; Table 1) were relatively dispersed among the shedding patterns of the inoculated animals.

In general, birds inoculated with the H4N6 virus were more susceptible to infection and excreted more viral RNA than birds inoculated with the H5N8 virus. Only four of 24 pigeons inoculated with the $\mathrm{H} 5 \mathrm{~N} 8$ virus excreted detectable levels of viral RNA in oral swabs for more than one day post-inoculation. In contrast, 10 of 23 pigeons inoculated with the H4N6 virus excreted virus on at least two days post-inoculation. Similarly, only one inoculated H5N8 pigeon shed viral RNA at 4 dpi while three H4N6inoculated pigeons were positive at both 4 and 5 dpi. Three fecal swabs from three different H5N8 birds on three different days were positive for viral RNA, but all values were lower than $10^{2}$ EID $_{50}$ PCR equivalents/mL. All fecal swabs

Table 1 Quantitative RT-PCR and serology results for pigeons inoculated with H5N8 and H4N6 low-pathogenic avian influenza A viruses

\begin{tabular}{|c|c|c|c|c|c|c|c|c|c|c|c|c|c|c|c|c|}
\hline \multirow[t]{2}{*}{ H5N8 } & \multirow[t]{2}{*}{ ID } & \multicolumn{5}{|c|}{$\log _{10}$ EID $_{50}$ PCR equivalents/mL } & \multirow{2}{*}{$\begin{array}{l}\text { AGID } \\
11 \\
\text { dpi }\end{array}$} & \multirow{2}{*}{$\begin{array}{l}\text { ELISA } \\
16 \text { or } 18 \\
\text { dpi }\end{array}$} & \multirow[t]{2}{*}{ H4N6 } & \multirow[t]{2}{*}{ ID } & \multicolumn{5}{|c|}{$\log _{10}$ EID $_{50}$ PCR equivalents/mL } & \multirow{2}{*}{$\begin{array}{l}\text { ELISA } \\
7,15,21 \text {, or } 28 \\
\text { dpi }\end{array}$} \\
\hline & & $\begin{array}{l}1 \\
\text { dpi }\end{array}$ & $\begin{array}{l}2 \\
\text { dpi }\end{array}$ & $\begin{array}{l}3 \\
\text { dpi }\end{array}$ & $\begin{array}{l}4 \\
\text { dpi }\end{array}$ & $\begin{array}{l}5 \\
\text { dpi }\end{array}$ & & & & & $\begin{array}{l}1 \\
\text { dpi }\end{array}$ & $\begin{array}{l}2 \\
\text { dpi }\end{array}$ & $\begin{array}{l}3 \\
\text { dpi }\end{array}$ & $\begin{array}{l}4 \\
\text { dpi }\end{array}$ & $\begin{array}{l}5 \\
\text { dpi }\end{array}$ & \\
\hline & 44 & - & 2.85 & - & - & - & $\mathrm{N}$ & $\mathrm{P}$ & & 49 & 2.95 & 4.19 & 3.23 & 1.63 & 2.41 & $\mathrm{P}$ \\
\hline & 9 & 3.33 & 2.62 & 1.63 & 1.60 & - & WP & $\mathrm{P}$ & & 58 & 3.43 & 2.11 & - & - & 1.09 & $\mathrm{P}$ \\
\hline & 7 & 1.65 & 2.62 & - & - & - & WP & $\mathrm{N}$ & & 48 & 2.85 & 1.98 & 1.43 & - & - & $\mathrm{P}$ \\
\hline & 11 & 1.55 & 2.57 & 1.19 & - & - & WP & $\mathrm{P}$ & & 47 & 2.54 & 1.71 & 1.23 & - & - & $S$ \\
\hline & 30 & - & 2.43 & - & - & - & $\mathrm{N}$ & $\mathrm{P}$ & & 61 & 3.06 & 1.51 & 1.15 & - & 2.00 & $\mathrm{P}$ \\
\hline & 37 & 1.47 & 1.13 & - & - & - & $\mathrm{N}$ & $\mathrm{N}$ & & 46 & - & 1.48 & 1.16 & - & - & $\mathrm{P}$ \\
\hline & 26 & 2.94 & - & - & - & - & $\mathrm{N}$ & $\mathrm{N}$ & & 55 & 2.85 & 1.44 & - & - & - & $\mathrm{P}$ \\
\hline & 27 & 2.49 & - & - & - & - & $\mathrm{N}$ & $\mathrm{P}$ & & 45 & 2.84 & 1.28 & - & - & - & $\mathrm{N}$ \\
\hline & 32 & 2.48 & - & - & - & - & $\mathrm{N}$ & $\mathrm{S}$ & & 59 & 1.77 & - & 1.26 & 1.88 & - & $\mathrm{N}$ \\
\hline & 42 & 2.46 & - & - & - & - & $\mathrm{N}$ & $\mathrm{P}$ & & 50 & 1.42 & - & 1.18 & 1.10 & - & $\mathrm{P}$ \\
\hline & 12 & 2.32 & - & - & - & - & $\mathrm{N}$ & $\mathrm{S}$ & & 33 & 2.71 & - & - & - & - & $\mathrm{P}$ \\
\hline & 31 & 2.14 & - & - & - & - & $\mathrm{N}$ & $\mathrm{N}$ & & 51 & 2.49 & - & - & - & - & $\mathrm{P}$ \\
\hline & 40 & 2.14 & - & - & - & - & $\mathrm{N}$ & $\mathrm{P}$ & & 56 & 2.43 & - & - & - & - & $\mathrm{N}$ \\
\hline & 36 & 2.05 & - & - & - & - & $\mathrm{N}$ & $S$ & & 52 & 2.14 & - & - & - & - & $\mathrm{P}$ \\
\hline & 39 & 1.62 & - & - & - & - & $\mathrm{N}$ & $\mathrm{N}$ & & 64 & 2.21 & - & - & - & - & $\mathrm{N}$ \\
\hline & 28 & 1.45 & - & - & - & - & $\mathrm{N}$ & $\mathrm{N}$ & & 38 & 1.98 & - & - & - & - & $\mathrm{N}$ \\
\hline & 4 & - & - & - & - & - & WP & $\mathrm{N}$ & & 53 & 1.26 & - & - & - & - & $\mathrm{N}$ \\
\hline & 41 & - & - & - & - & - & WP & $\mathrm{N}$ & & 62 & 1.08 & - & - & - & - & $\mathrm{N}$ \\
\hline & 2 & - & - & - & - & - & $\mathrm{N}$ & $\mathrm{N}$ & & 13 & - & - & - & - & - & $\mathrm{N}$ \\
\hline & 6 & - & - & - & - & - & $\mathrm{N}$ & $\mathrm{S}$ & & 34 & - & - & - & - & - & $\mathrm{N}$ \\
\hline & 14 & - & - & - & - & - & $\mathrm{N}$ & $\mathrm{N}$ & & 57 & - & - & - & - & - & $S$ \\
\hline & 29 & - & - & - & - & - & $\mathrm{N}$ & $\mathrm{S}$ & & 60 & - & - & - & - & - & $\mathrm{N}$ \\
\hline & 35 & - & - & - & - & - & $\mathrm{N}$ & $\mathrm{N}$ & & 63 & - & - & - & - & - & $\mathrm{N}$ \\
\hline & 43 & - & - & - & - & - & $\mathrm{N}$ & $\mathrm{N}$ & & & & & & & & \\
\hline & $\% \mathrm{P}$ & 58 & 25 & 8 & 4 & 0 & 21 & 21 & & $\% \mathrm{P}$ & 74 & 35 & 30 & 13 & 13 & 24 \\
\hline
\end{tabular}

dpi, days post-inoculation; $\mathrm{P}$, positive; WP, weakly positive; $\mathrm{S}$, suspect positive; $\mathrm{N}$, negative

ELISA results are presented as positive if at least one sample was positive (sample-to-negative-control ratio $[\mathrm{S} / \mathrm{N}]=0.6$ or less) or suspect positive ( $\mathrm{S} / \mathrm{N}$ ratio between 0.6 and 0.7 ). All oral swabs for 5-7 dpi were negative for birds inoculated with the H5N8 virus, and all oral swabs for 6-7 dpi were negative for birds inoculated with the H4N6 virus 
for birds inoculated with the H4N6 virus, all cloacal swabs for both viruses, and all sample types from controls and contact controls were negative by RT-qPCR. One of the contact control pigeons was housed with ID34, which did not shed any detectable viral RNA, and the other was housed with ID51, which only shed detectable viral RNA $\left(10^{2.49} \mathrm{EID}_{50}\right.$ equivalents/mL) at $1 \mathrm{dpi}$.

Serum samples were screened for antibodies to IAV via the IDEXX ELISA, which has not been validated for pigeons. A study of the ELISA applied to samples from multiple avian species found that the manufacturer's recommended threshold of $<0.5$ missed $18 \%$ of presumed positive samples across more than 20 experimentally infected wild bird species and that a threshold of 0.7 was optimal for correct classification [3]. Similarly, another study found that a threshold of 0.7 was optimal for more than 800 samples from naïve and experimentally inoculated mallards [18]. In the current study, pre-screened birds exhibited a mean $\mathrm{S} / \mathrm{N}$ ratio of 0.85 (range, 0.74-1.03). Therefore, to improve classification, we applied a threshold of $\mathrm{S} / \mathrm{N}$ ratio $<0.6$ to identify positive samples and classified samples with $\mathrm{S} / \mathrm{N}$ values between 0.6 and 0.7 as suspect positive.

Similar to the RT-qPCR results, pigeons inoculated with the H4N6 virus seroconverted at higher rates than pigeons inoculated with the H5N8 virus (Table 1). Serological tests showed that five of the 24 pigeons inoculated with the H5N8 virus $(21 \%)$ were weakly positive by AGID test at 11 dpi, seven (33\%) were positive by ELISA at either 16 or $18 \mathrm{dpi}$, and five $(21 \%)$ were suspect positive by ELISA at 16 or $18 \mathrm{dpi}$. For the birds inoculated with the H4N6 virus, 10 of 23 birds (43\%) were positive by ELISA (i.e., they showed at least one positive result at $7,15,21$, or 28 dpi), and two of the birds (9\%) were suspect positive.

For the H4N6-inoculated birds sampled weekly through $28 \mathrm{dpi}$, eight of the 10 birds that seroconverted were positive at 7 dpi (Table 2), with the remaining two pigeons classified as positive at $15 \mathrm{dpi}$. The two suspect positive birds rated that designation at $7 \mathrm{dpi}$ but were negative at subsequent sampling times. Only four of the 10 positive birds remained positive at $28 \mathrm{dpi}$, with one moving into the suspect positive range. Overall, serologic responses showed a trend of peak response at 7 or $14 \mathrm{dpi}$, followed by a decline in activity by 21 and $28 \mathrm{dpi}$. The exception to this trend was a single bird (ID 49) that showed a monotonic decrease in $\mathrm{S} / \mathrm{N}$ ratios across the sampling period (i.e., the bird showed a stronger serologic response over time). Notably, this was the single individual that shed more viral RNA than any other inoculated individual (Table 1). Another individual (ID 55) showed a stable positive serologic response across the sampling periods. The other two birds that remained positive at 28 dpi showed the general pattern of decreasing serologic response at $28 \mathrm{dpi}$.
Table 2 Sample-to-negative ratio values for IDEXX ELISA for pigeons inoculated with the H4N6 low-pathogenic influenza A virus

\begin{tabular}{llllll}
\hline Bird & 0 dpi & 7 dpi & 15 dpi & 21 dpi & 28 dpi \\
\hline 49 & 0.95 & $0.32^{* *}$ & $0.26^{* *}$ & $0.15^{* *}$ & $0.12^{* *}$ \\
58 & 0.84 & 0.73 & $0.55^{* *}$ & $0.66^{*}$ & 0.74 \\
48 & 0.92 & $0.33^{* *}$ & $0.61^{*}$ & $0.66^{*}$ & 0.89 \\
47 & 0.91 & $0.64 *$ & 0.81 & 0.86 & 0.84 \\
61 & 0.92 & $0.67 *$ & $0.59^{* *}$ & $0.65^{*}$ & $0.62^{*}$ \\
46 & 0.92 & $0.58^{* *}$ & $0.27 * *$ & $0.42^{* *}$ & $0.54^{* *}$ \\
55 & 0.84 & $0.37 * *$ & $0.30^{* *}$ & $0.31^{* *}$ & $0.31^{* *}$ \\
45 & 0.98 & 1.63 & 0.85 & 0.88 & 0.94 \\
59 & 0.93 & 0.86 & 0.86 & 0.93 & 0.90 \\
50 & 0.89 & $0.43 * *$ & $0.54 * *$ & $0.59^{* *}$ & 0.73 \\
33 & 0.92 & $0.53 * *$ & 0.74 & 0.77 & 0.87 \\
51 & 0.88 & $0.54 * *$ & $0.48^{* *}$ & $0.32^{* *}$ & $0.53 * *$ \\
56 & 0.79 & 0.79 & 0.84 & 0.89 & 0.89 \\
52 & 0.89 & $0.52^{* *}$ & $0.54 * *$ & $0.67 *$ & 0.79 \\
64 & 0.86 & 0.72 & 0.84 & 0.89 & 0.89 \\
38 & 0.95 & 0.75 & 0.93 & 0.92 & 0.95 \\
53 & 0.88 & 0.80 & 0.76 & 0.88 & 0.87 \\
62 & 0.90 & 0.94 & 0.92 & 0.91 & 0.91 \\
13 & 0.92 & 0.83 & 0.85 & 0.84 & 0.89 \\
34 & 0.89 & 0.78 & 0.91 & 0.94 & 0.93 \\
57 & 0.88 & $0.66 *$ & 0.82 & 0.92 & 0.90 \\
60 & 0.87 & 0.94 & 0.89 & 0.89 & 0.95 \\
63 & 0.89 & 0.88 & 0.85 & 0.87 & 0.82 \\
\hline
\end{tabular}

dpi, days post-inoculation

Doubly starred values are positive $(\mathrm{S} / \mathrm{N}$ ratio $<0.6)$

Singly starred values are suspect positive ( $\mathrm{S} / \mathrm{N}$ ratio $0.6-0.7)$

Our results corroborate previous studies indicating that pigeons have limited susceptibility to LP IAV infection and that individuals that become infected excrete relatively low levels of virus, primarily associated with oral shedding. However, individual heterogeneity was apparent, and at least one of 23 individuals inoculated with the H4N6 virus shed viral RNA in quantities potentially sufficient for transmission to other birds. Overall, the birds in this study exhibited higher shedding rates than were observed in previous experimental inoculations of pigeons with LP IAVs $[5,6,11]$.

In our serosurvey at the LP H5N8 outbreak site, only $13 \%$ of pigeons were positive for antibodies to IAVs, and only one of those individuals showed evidence for possible exposure to the outbreak H5N8 virus (via a positive NI test for N8) a month after the outbreak. This relatively low seroprevalence may be a result of the one-month time lag between the outbreak and sample collection or because the exposures that we found were associated with other subtypes, and those exposures may have occurred even further 
out and antibody levels may have begun to wane after primary exposure. For perspective, our experimental inoculation with H4N6 showed that half of the seropositive birds in that experiment were negative by $28 \mathrm{dpi}$.

Our experimental inoculation of pigeons with the H5N8 virus showed relatively low susceptibility to the virus. Only a quarter of the birds shed detectable RNA for more than a day and only half of the birds seroconverted. In contrast, the experimental inoculation with an H4N6 LP IAV showed somewhat higher susceptibility and shedding rates compared to what was observed with the birds inoculated with the H5N8 virus. About a third of birds shed detectable RNA for at least two days, with one individual excreting viral RNA daily for five days.

A risk-assessment model for the spread of H5N1 HP IAVs [2] showed that farms in Bangladesh had a higher risk of an outbreak if pigeons were present, but these authors suggested that the threat is likely to be associated with potential mechanical transmission rather than from excreted virus. Our results corroborate that suggestion as a possibility but also show that, in some cases, an individual might shed virus in a manner consistent with potential transmission to other birds. The differences in shedding rates and immunity between the tested subtypes indicate that susceptibility in pigeons is likely strain dependent, such that spillover to pigeons is likely to be associated with the subtypes circulating in poultry and wild birds. Therefore, this species cannot be completely ruled out in biosecurity plans aimed at limiting wildlife intrusions onto poultry farms. We conclude, as others have [1, 5, 6, 9, 11], that pigeons generally play a negligible, but non-zero role in IAV dynamics.

Acknowledgments We thank the National Veterinary Services Laboratories in Ames, IA, for providing the H5N8 virus, George Graves of USDA/APHIS/WS for logistical support, Daniel N. Gossett and the National Wildlife Research Center Animal Care Staff for animal husbandry, and Gordon R. Gathright for veterinary support. We also thank two anonymous reviewers for providing excellent comments.

\section{References}

1. Abolnik C (2014) A current review of avian influenza in pigeons and doves (Columbidae). Vet Microbiol 170:181-196. doi:10. 1016/j.vetmic.2014.02.042

2. Biswas PK, Islam MZ, Debnath NC, Yamage M (2014) Modeling and roles of meteorological factors in outbreaks of highly pathogenic avian influenza H5N1. PLoS One. doi:10.1371/jour nal.pone.0098471

3. Brown JD, Stallknecht DE, Berghaus RD, Luttrell MP, Velek K, Kistler W, Costa T, Yabsley MJ, Swayne D (2009) Evaluation of a commercial blocking enzyme-linked immunosorbent assay to detect avian influenza virus antibodies in multiple experimentally infected avian species. Clin Vaccine Immunol 16:824-829
4. Carlson JC, Clark L, Antolin MF, Salman MD (2011) Rock pigeon use of livestock facilities in northern colorado: implications for improving farm bio-security. Human Wildl Interact $5: 112-122$

5. Fang TH, Lien YY, Cheng MC, Tsai HJ (2006) Resistance of immune-suppressed pigeons to subtypes H5N2 and H6N1 low pathogenic avian influenza virus. Avian Dis 50:269-272. doi:10. 1637/7437-090905R.1

6. Guan Y, Shortridge KF, Krauss S, Chin PS, Dyrting KC, Ellis TM, Webster RG, Peiris M (2000) H9N2 influenza viruses possessing H5N1-like internal genomes continue to circulate in poultry in southeastern China. J Virol 74:9372-9380. doi:10. 1128/JVI.74.20.9372-9380.2000

7. Jankowski MD, Williams CJ, Fair JM, Owen JC (2013) Birds shed RNA-viruses according to the Pareto Principle. PLoS One. doi:10.1371/journal.pone.0072611

8. Jia B, Shi J, Li Y, Shinya K, Muramoto Y, Zeng X, Tian G, Kawaoka Y, Chen H (2008) Pathogenicity of Chinese H5N1 highly pathogenic avian influenza viruses in pigeons. Arch Virol 153:1821-1826. doi:10.1007/s00705-008-0193-8

9. Kaleta EF, Hönicke A (2004) Review of the literature on avian influenza A viruses in pigeons and experimental studies on the susceptibility of domestic pigeons to influenza A viruses of the haemagglutinin subtype H7. Deut Tierarztl Woch 111:467-472

10. Liu Y, Zhou J, Yang H, Yao W, Bu W, Yang B, Song W, Meng Y, Lin J, Han C, Zhu J, Ma Z, Zhao J, Wang X (2007) Susceptibility and transmissibility of pigeons to Asian lineage highly pathogenic avian influenza virus subtype H5N1. Avian Pathol 36:461-465. doi:10.1080/03079450701639335

11. Panigrahy B (1996) Susceptibility of pigeons to avian influenza. Avian Dis 40:600-604

12. Pepin KM, VanDalen KK, Mooers NL, Ellis JW, Sullivan HJ, Root JJ, Webb CT, Franklin AB, Shriner SA (2012) Quantification of heterosubtypic immunity between avian influenza subtypes H3N8 and H4N6 in multiple avian host species. J Gen Virol 93:2575-2583

13. Perkins LEL, Swayne DE (2002) Susceptibility of laughing gulls (Larus atricilla) to $\mathrm{H} 5 \mathrm{~N} 1$ and $\mathrm{H} 5 \mathrm{~N} 3$ highly pathogenic avian influenza viruses. Avian Dis 46:877-885

14. Phonaknguen R, Chaichoun K, Wiriyarat W, Sariya L, Prayoowong N, Chaisilp N, Moonjit P, Puthavathana P, Auewarakul P, Ratanakorn P, Songserm T (2013) Minimal susceptibility to highly pathogenic avian influenza H5N1 viral infection of pigeons (Columba livia) and potential transmission of the virus to comingled domestic chickens. Kasetsart J - Nat Sci 47:720-732

15. Piaggio AJ, Shriner SA, VanDalen KK, Franklin AB, Anderson TD, Kolokotronis SO (2012) Molecular surveillance of low pathogenic avian influenza viruses in wild birds across the United States: inferences from the hemagglutinin gene. PLoS One. doi:10.1371/journal.pone.0050834

16. Senne DA (2007) Avian influenza in North and South America, 2002-2005. Avian Dis 51:167-173

17. Shriner SA, VanDalen KK, Mooers NL, Ellis JW, Sullivan HJ, Root JJ, Pelzel AM, Franklin AB (2012) Low-pathogenic Avian influenza viruses in wild house mice. PLoS One. doi:10.1371/ journal.pone.0039206

18. Shriner SA, VanDalen K, Root JJ, Sullivan H (2016) Evaluation and optimization of a commercial influenza A blocking ELISA for research and surveillance of mallards. J Virol Methods 228:130-134. doi:10.1016/j.jviromet.2015.11.021

19. Śmietanka K, Minta Z, Wyrostek K, Jóźwiak M, Olszewska M, Domańska-Blicharz K, Reichert M, Pikuła A, Habyarimana A, Van Den Berg T (2011) Susceptibility of pigeons to clade 1 and 2.2 high pathogenicity avian influenza H5N1 virus. Avian Dis 55:106-112 
20. Spackman E, Senne DA, Myers TJ, Bulaga LL, Garber LP, Perdue ML, Lohman K, Daum LT, Suarez DL (2002) Development of a real-time reverse transcriptase PCR assay for type A influenza virus and the avian $\mathrm{H} 5$ and $\mathrm{H} 7$ hemagglutinin subtypes. J Clin Microbiol 40:3256-3260

21. Szretter KJ, Balish AL, Katz JM (2006) Influenza: propagation, quantification, and storage. Curr Protoc Microbiol Chapter 15 :Unit $15 \mathrm{G} .1$

22. VanDalen KK, Franklin AB, Mooers NL, Sullivan HJ, Shriner SA (2010) Shedding light on avian influenza H4N6 infection in mallards: Modes of transmission and implications for surveillance. PLoS One. doi:10.1371/journal.pone.0012851
23. Werner O, Starick E, Teifke J, Klopfleisch R, Prajitno TY, Beer M, Hoffmann B, Harder TC (2007) Minute excretion of highly pathogenic avian influenza virus A/chicken/Indonesia/2003 (H5N1) from experimentally infected domestic pigeons (Columba livia) and lack of transmission to sentinel chickens. J Gen Virol 88:3089-3093

24. Yamamoto Y, Nakamura K, Yamada M, Mase M (2012) Limited susceptibility of pigeons experimentally inoculated with $\mathrm{H} 5 \mathrm{~N} 1$ highly pathogenic avian influenza viruses. J Vet Med Sci 74:205-208 